\title{
REAKSI PASAR MODAL SYARIAH TERHADAP AKSI BELA ISLAM 212 DI JAKARTA
}

\author{
MUHAMMAD AGUS FAUZI, NUR ICHSAN \\ Fakultas Ekonomi, Universitas Wahid Hasyim \\ Muhammadagusfauzi1989@gmail.com
}

\begin{abstract}
ABSTRAK
Penelitian ini dilakukan untuk mengkaji apakah pasar modal syariah memberikan respon terhadap gejolak yang terjadi pada aksi bela Islam 212. Untuk mengkaji hal tersebut, maka penelitian ini menggunakan uji paired sample t-test, yang dalam hal ini diambil sampel berupa saham-saham syariah yang terdaftar di Jakarta Islamic Index (JII).

Hasil penelitian menunjukkan bahwa volume transaksi saham syariah mengalami perbedaan antara sebelum dan sesudah aksi bela Islam 212 dengan tren meningkat setelah aksi. Sementara itu, return saham syariah tidak mengalami perbedaan. Dengan demikian, dapat disimpulkan bahwa sebelum aksi bela Islam 212, sebagian investor saham syariah cenderung untuk menahan saham yang mereka miliki, sedangkan sebagian yang lain tetap melakukan transaksi secara rasional sehingga laba tetap menjadi prioritas utama dalam transaksi yang dilakukan.
\end{abstract}

\section{Kata Kunci: Pasar Modal Syariah, Saham Syariah, Aksi Bela Islam 212}

\section{PENDAHULUAN}

\section{Latar Belakang}

Pada Oktober 2016, Indonesia dihebohkan oleh kutipan video yang berjudul 'Penistaan Terhadap Agama'. Video ini merupakan potongan dari video kunjungan kerja Basuki Tjahja Purnama, Gubernur DKI Jakarta, di Pulau Pramuka yang berlokasi di Kepulauan Seribu. Video ini diklaim oleh beberapa pihak memuat penistaan terhadap kitab suci umat Islam. Sebagai respon dari video ini, banyak ormas Islam yang menggelar serangkaian aksi unjuk rasa yang dipusatkan di Jakarta. Aksi ini di-branded dengan nama "Áksi Bela Islam".
Aksi bela Islam tercatat digelar sebanyak enam kali, yaitu pada 14 Oktober 2016, 4 November 2016 (Aksi Damai 411), 2 Desember 2016 (Aksi Damai 212), 11 Februari 2017 (Aksi 112), 21 Februari 2017 (Aksi 212), dan 31 Maret 2017 (Aksi 313). Serangkaian aksi ini diikuti oleh ribuan umat Islam di Jakarta. Bahkan, pada Aksi Damai 212, ratusan ribu massa yang berasal dari seluruh penjuru Indonesia ikut bergabung dalam aksi ini.

Dengan jumlah massa yang fantastis, Aksi Bela Islam ini praktis berdampak bagi perekenomian, tidak hanya dalam skala wilayah, tetapi juga nasional. Bahkan, bisa jadi aksi ini juga 
memberikan reaksi pasar modal syariah. Dampak aksi ini terhadap pasar modal inilah yang dinamakan dengan anomali pasar modal.

Secara harfiah, anomali berarti penyimpangan atau ketidaknormalan (KBBI, 2003). Sedangkan dalam konteks pasar keuangan, anomali merupakan penyimpangan harga saham yang menyebabkan abnormal return bagi investor. Jones (1996) mengemukakan bahwa anomali menyebabkan pergerakan pasar tidak lagi acak sebagaimana pasar efisien, melainkan terstruktur pada waktuwaktu tertentu. Pergerakan ini diprediksi oleh para investor dan digunakan sebagai pertimbangan untuk menghasilkan return yang lebih tinggi.

Return merupakan tingkat keuntungan atau kerugian dari suatu investasi pada periode tertentu (Evianti, 2007). Return yang diperoleh dari suatu investasi saham dapat berupa deviden (jika ada) dan capital gain, yaitu keuntungan yang dihitung melalui selisih harga jual saham dengan harga belinya (Imandani, 2008). Return dari capital gain inilah yang dihitung untuk mengetahui ada tidaknya anomali pasar.

Dalam teori keuangan, ada empat macam anomali pasar, yaitu anomali perusahaan (firm anomalies), anomali musiman (seasonal anomalies), anomali peristiwa (event anomalies), serta anomali akuntansi/accounting anomalies (Levy, 1996). Dampak Aksi Bela Islam terhadap pasar modal ini tergolong sebagai anomali peristiwa/event anomalies.

Para peneliti pasar modal telah banyak melakukan riset terhadap anomali pasar, diantaranya:

1. Iqbal et al (2013), yang meneliti anomali kalender pada Karachi Stock Exchange (KSE) di Pakistan. Penelitian ini menyimpulkan bahwa terdapat efek negative Monday dan positive Friday di KSE. Selain itu, efek half of the month, turn of the month, turn of the year, dan ramadan juga signifikan terjadi di KSE Pakistan.

2. Raj dan Kumari (2006), yang menganalisa pasar modal di India dengan melakukan pendekatan return harian dan mingguan. Riset ini tidak berhasil membuktikan adanya negative Monday dan positive January effect di India.

3. Fazal et al (2005) dengan penelitian yang berjudul "Seasonality in Stock return and Volatility: The Ramadan Effect". Penelitian yang dilakukan terhadap bursa saham di Saudi Arabia ini menunjukkan bahwa selama bulan Ramadhan terjadi kemerosotan transaksi saham, sehingga aktivitas pasar berjalan perlahan. 
4. Hepsen (2012), yang membahas anomali kalender pada saham properti di Turki. Penelitian ini menghasilkan kesimpulan bahwa secara signifikan terdapat January effect dan negative Monday di Turki.

5. Al-Rabadi dan Al-Qudah (2012), yang telah meneliti anomali kalender di Amman Stock Exchange (ASE), Jordania. Penelitian ini menyimpulkan bahwa di Jordania secara signifikan terdapat positive Monday, positive Friday dan January effect.

6. Depenchuk et al (2010), yang meneliti pasar modal Ukraina. Penelitian ini diberi judul "Ukrainian financial markets: an examination of calendar anomalies". Hasilnya, tidak terdapat January effect dan Monday effect di Ukraina. Pasar modal di negara ini terbukti signifikan hanya memiliki turn of month anomalie.

7. Imandani (2008), yang melakukan penelitian tentang holiday effect di Bursa Efek Indonesia (BEI). Penelitian ini memeroleh kesimpulan bahwa holiday effect di Indonesia berhasil teridentifikasi.

Penelitian-penelitian di atas (serta penelitian lain yang tidak disebut) kebanyakan mengambil kasus anomali musiman/seasonal anomalies. Masih jarang penelitian yang mengkaji event anomalies, seperti peristiwa pada aksi bela Islam yang terjadi di Indonesia pada beberapa waktu yang lalu. Penelitian terdahulu juga lebih banyak mengambil bursa efek konvensional sebagai objek penelitiannya. Bursa efek syariah masih sedikit dijadikan kajian oleh para peneliti. Dari research gap tersebut, maka penelitian ini akan mengkaji anomali peristiwa pada saham syariah dengan menggunakan judul, "Reaksi Pasar Modal Syariah Terhadap Aksi Bela Islam 212 di Jakarta”.

\section{Permasalahan Penelitian}

Dari latar belakang tersebut, maka permasalahan yang diusung dalam penelitian ini adalah:

1. Apakah terdapat perbedaan volume perdagangan saham syariah sebelum dan sesudah aksi bela Islam 212 di Jakarta?

2. Apakah terdapat abnormal return saham syariah antara sebelum dan sesudah aksi bela Islam 212 di Jakarta?

\section{Tujuan Penelitian}

Berpijak pada permasalahan yang dirumuskan, maka penelitian ini bertujuan untuk mengetahui ada/tidaknya:

1. perbedaan volume perdagangan saham syariah sebelum dan sesudah aksi bela 
Islam 212 di Jakarta.

2. abnormal return saham syariah sebelum dan sesudah aksi bela Islam 212 di Jakarta.

\section{Urgensi Penelitian}

Penelitian ini memberikan urgensi kepada banyak pihak, diantaranya:

1. Bagi akademisi

a. Memperkaya khazanah penelitian saham syariah dari perspektif event anomalies.

2. Bagi musahim saham syariah

a. Mengetahui dampak gejolak aktifitas umat Islam terhadap pergerakan saham syariah

b. Informasi untuk mengetahui pergerakan saham syariah dalam event-event insisdental.

3. Bagi pemerintah

a. Bahan pertimbangan dalam menyusun kebijakan antisipatif yang dapat mempertahankan kestabilan pergerakan saham syariah apabila terjadi peristiwa yang serupa

\section{KAJIAN PUSTAKA}

\section{Pasar Modal yang Efisien}

Gumanti \& Utami

menyebutkan bahwa salah satu terobosan penting dalam perkembangan teori keuangan perusahaan adalah dikedepankannya hipotesis pasar efisien (Efficient-Market Hypothesis) oleh Fama di tahun 1970. Suatu pasar dikatakan efisien apabila tidak seorangpun, baik investor individu maupun investor institusi, akan mampu memperoleh abnormal return dalam jangka waktu yang lama dengan menggunakan strategi perdagangan yang ada. Artinya, harga harga yang terbentuk di pasar merupakan cerminan dari informasi yang ada (stock prices reflect all available information).

Jika pasar bereaksi dengan cepat dan akurat untuk mencapai harga keseimbangan baru yang sepenuhnya mencerminkan informasi yang tersedia, maka kondisi pasar seperti ini disebut dengan pasar efisien (Jogiyanto, 2003). Fama (1970) dalam Jogiyanto (2003) membagi efisiensi pasar modal dalam tiga tingkatan, yaitu :

1. Efisiensi Bentuk Lemah (Weak-Form Efficiency

Pasar dikatakan efisien dalam bentuk lemah jika harga - harga dari sekuritas tercermin secara penuh (fully reflect) informasi masa lalu. Informasi masa lalu ini merupakan informasi yang sudah terjadi. Bentuk efisiensi secara lemah ini berkaitan dengan teori acak (random-walk theory) yang menyatakan bahwa data masa lalu tidak berhubungan dengan nilai 
sekarang. Jika pasar efisien 23 secara bentuk lemah, maka nilai - nilai masa lalu tidak dapat digunakan untuk memprediksi harga sekarang. Implikasinya adalah investor tidak dapat menggunakan informasi masa lalu untuk mendapatkan keuntungan yang tidak normal.

2. Efisiensi Bentuk Setengah Kuat (Semistrong-Form Efficiency)

Pasar dikatakan efisien setengah kuat jika harga - harga sekuritas secara penuh mencerminkan (fully reflect) semua informasi yang dipublikasikan (all publicly available information) termasuk informasi yang berada di laporan-laporan keuangan perusahaan emiten. Implikasinya adalah tidak ada investor atau grup dari investor yang dapat menggunakan informasi yang dipublikasikan untuk mendapatkan keuntungan tidak normal dalam jangka waktu yang lama.

3. Efisiensi Bentuk Kuat (Strong-Form Efficiency)

Pasar modal yang efisien dalam bentuk kuat merupakan tingkat efisiensi pasar yang tertinggi. Pasar dikatakan efisien dalam bentuk kuat jika harga - harga sekuritas secara penuh mencerminkan (fully reflect) semua informasi yang tersedia termasuk informasi yang privat. Implikasinya adalah bahwa tidak ada individual investor atau grup dari investor, meskipun dengan kemampuan yang superior, mampu memperoleh abnormal return dengan menggunakan semua informasi yang relevan, baik historis, yang dipublikasikan, maupun yang tidak dipublikasikan.

Agar pasar efisien ada dalam kehidupan nyata, terdapat beberapa kondisi yang idealnya harus terpenuhi atau didekati oleh kenyataan yang ada di pasar (Jogiyanto, 2003) :

1. Investor adalah penerima harga (price takers), yang berarti bahwa sebagai pelaku pasar, investor seorang diri tidak dapat mempengaruhi harga dari suatu

sekuritas. Harga dari suatu sekuritas ditentukan oleh banyak investor yang menentukan demand dan supply. Hal ini dapat terjadi jika pelaku - pelaku pasar terdiri dari sejumlah besar individu dan institusi rasional yang mampu mengartikan dan menginterpretasikan informasi dengan baik untuk digunakan menganalisis, menilai, dan melakukan transaksi.

2. Informasi tersedia secara luas kepada semua pelaku pasar pada saat yang bersamaan dan harga untuk memperoleh informasi tersebut murah. Informasi yang ada dapat dengan 
mudah diperoleh dan hampir setiap saat sama seperti halnya informasi yang disampaikan lewat radio atau televisi. Fleksibilitas dan bervariasinya sumber dan jenis informasi memungkinkan investor untuk mendapatkan informasi secara gratis.

3. Informasi dihasilkan secara acak (random) dan tiap - tiap pengumuman informasi sifatnya random satu dengan yang lainnya. Informasi dihasilkan secara random mempunyai arti bahwa investor tidak dapat memprediksi kapan emiten akan mengumumkan informasi baru yang penting, kapan perang akan terjadi, atau kapan pemogokan tenaga kerja akan terjadi. Walaupun ada ketergantungan terhadap beberapa informasi sepanjang waktu, tetap saja bahwa pengumuman suatu peristiwa, misalnya adanya corporate actions, adalah independen dan dapat muncul setiap saat, dengan kata lain acak.

4. Investor bereaksi dengan cepat dan sepenuhnya terhadap informasi baru yang masuk di pasar, yang menyebabkan harga sekuritas segera mengalami penyesuaian untuk mencapai keseimbangan yang baru.

\section{Anomali Pasar}

Secara harfiah, anomali berarti penyimpangan atau ketidaknormalan (KBBI, 2003). Sedangkan dalam konteks pasar keuangan, anomali merupakan penyimpangan harga saham yang menyebabkan abnormal return bagi investor. Jones (1996) mengemukakan bahwa anomali menyebabkan pergerakan pasar tidak lagi acak sebagaimana pasar efisien, melainkan terstruktur pada waktuwaktu tertentu. Pergerakan ini diprediksi oleh para investor dan digunakan sebagai pertimbangan untuk menghasilkan return yang lebih tinggi.

Return merupakan tingkat keuntungan atau kerugian dari suatu investasi pada periode tertentu (Evianti, 2007). Return yang diperoleh dari suatu investasi saham dapat berupa deviden (jika ada) dan capital gain, yaitu keuntungan yang dihitung melalui selisih harga jual saham dengan harga belinya (Imandani, 2008). Return dari capital gain inilah yang dihitung untuk mengetahui ada tidaknya anomali pasar.

Dalam teori keuangan, ada empat macam anomali pasar, yaitu anomali perusahaan (firm anomalies), anomali musiman (seasonal anomalies), anomali peristiwa (event anomalies), serta anomali akuntansi/accounting anomalies (Levy, 1996). Yang seringkali terjadi sehingga 
menyebabkan pergerakan abnormal pasar mdoal adalah anomali peristiwa atau yang sering dikenal dengan event anomalies, yang kajian mengenai hal ini kemudian disebut dengan event study.

Event study adalah suatu pengamatan mengenai pergerakan harga saham di pasar modal untuk mengetahui apakah ada abnormal return yang diperoleh pemegang saham akibat dari suatu peristiwa tertentu (Peterson, 1989 dalam Suryawijaya \& Setiawan, 1998). Pengamatan itu biasanya dilakukan dengan melihat perilaku return saham di sekitar kejadian yang diamati. Sedangkan Jogiyanto (2003) menyebutkan bahwa event study merupakan studi yang mempelajari reaksi pasar terhadap suatu peristiwa (event) yang informasinya dipublikasikan sebagai suatu pengumuman.

Tujuan event study sebagaimana disebutkan oleh Kritzman (1994) adalah untuk mengukur hubungan antara suatu peristiwa yang mempengaruhi sekuritas dan return dari sekuritas tersebut. Selain itu event study dapat juga digunakan untuk mengukur dampak suatu peristiwa ekonomi terhadap nilai perusahaan (MacKinlay, 1997). Lamasigi (2002) menyimpulkan bahwa event study dikembangkan untuk menganalisis reaksi pasar terhadap suatu peristiwa yang informasinya dipublikasikan. Peristiwa tersebut meliputi peristiwa ekonomi maupun peristiwa non-ekonomi untuk mengetahui ada tidaknya abnormal return yang diperoleh pemegang saham. Selain itu, event study juga dapat digunakan untuk menguji kandungan informasi dari suatu peristiwa atau pengumuman. Jika suatu peristiwa atau pengumuman mengandung informasi maka pasar akan bereaksi pada waktu pengumuman tersebut diterima oleh pasar. Reaksi pasar ditunjukkan dengan adanya perubahan harga sekuritas bersangkutan. Reaksi ini biasanya diukur dengan menggunakan konsep abnormal return.

\section{Abnormal Return}

Tingkat keuntungan atau return merupakan tingkat kembalian yang dinikmati oleh investor atas suatu investasi yang dilakukannya. Menurut Ang (1997), tanpa adanya keuntungan yang dapat dinikmati dari suatu investasi, tentunya investor tidak akan mau berinvestasi. Lebih lanjut dijelaskan bahwa setiap investasi, baik jangka panjang maupun jangka pendek, mempunyai tujuan utama yaitu untuk mendapatkan keuntungan.

Reaksi pasar akibat terjadinya suatu peristiwa biasanya mengamati perubahan harga saham yang diukur dengan adanya abnormal return. Sebagaimana disebutkan dalam Jogiyanto (2003) bahwa jika digunakan abnormal return, maka dapat 
dikatakan bahwa suatu pengumuman yang memiliki kandungan informasi akan memberikan abnormal return kepada pasar. Sebaliknya yang tidak mengandung informasi tidak memberikan abnormal return kepada pasar.

Abnormal return menurut Jogiyanto (2003) adalah selisih antara tingkat keuntungan sebenarnya (actual return) dengan tingkat keuntungan yang diharapkan (expected return). Abnormal return atau excess return ini merupakan kelebihan dari return yang sesungguhnya terjadi terhadap return normal. Return normal merupakan return yang diharapkan oleh investor dengan mempertimbangkan tingkat risikonya. Brown \& Warner (1985) dalam Jogiyanto (2003) menyatakan bahwa expected return dapat dihitung dengan menggunakan tiga model estimasi, yaitu :

\section{Mean-adjusted Model}

Model disesuaikan rata - rata (meanadjusted model) ini menganggap bahwa return ekspektasi bernilai konstan yang sama dengan rata - rata return realisasi sebelumnya selama periode estimasi (estimation period).

\section{Market Model}

Model pasar (market model) merupakan bentuk dari model indeks tunggal yang didasarkan pada pengamatan bahwa harga dari suatu sekuritas berfluktuasi searah dengan indeks pasar. Secara khusus dapat diamati bahwa kebanyakan saham cenderung mengalami kenaikan harga jika indeks harga saham gabungan naik, begitu juga sebaliknya.

\section{Market-adjusted Model}

Model disesuaikan pasar (marketadjusted model) menganggap bahwa penduga yang terbaik untuk mengestimasi return suatu sekuritas adalah return dari indeks pasar pada saat tersebut. Dengan menggunakan model ini tidak perlu menggunakan periode estimasi untuk membentuk model estimasi, karena return sekuritas yang diestimasi adalah sama dengan return indeks pasar.

\section{Aksi Bela Islam}

Pada Oktober 2016, Indonesia dihebohkan oleh kutipan video yang berjudul 'Penistaan Terhadap Agama'. Video ini merupakan potongan dari video kunjungan kerja Basuki Tjahja Purnama, Gubernur DKI Jakarta, di Pulau Pramuka yang berlokasi di Kepulauan Seribu. Video ini diklaim oleh beberapa pihak memuat penistaan terhadap kitab suci umat Islam. Sebagai respon dari video ini, banyak ormas Islam yang menggelar serangkaian aksi unjuk rasa yang dipusatkan di Jakarta. Aksi ini di-branded dengan nama "Áksi Bela Islam". 
Aksi Bela Islam adalah rangkaian aksi unjuk rasa yang diadakan di Indonesia, terutama di Jakarta sebagai reaksi atas pernyataan gubernur Jakarta, Basuki Tjahaja Purnama yang mengeluarkan pernyataaan yang dianggap menistakan agama dalam kunjungan kerjanya ke Kepulauan Seribu (BBC Indonesia, 2016).

Aksi bela Islam tercatat digelar sebanyak enam kali, yaitu pada 14 Oktober 2016, 4 November 2016 (Aksi Damai 411), 2 Desember 2016 (Aksi Damai 212), 11 Februari 2017 (Aksi 112), 21 Februari 2017 (Aksi 212), dan 31 Maret 2017 (Aksi 313). Serangkaian aksi ini diikuti oleh ribuan umat Islam di Jakarta dan puncak acaranya digelar pada 2 Desember 2016 (Aksi 212) yang merupakan aksi ketiga yang dilaksanakan

\section{Studi Pendahuluan}

Sebagaimana dikutip dari MacKinlay (1997), event study memiliki sejarah yang panjang dalam penelitian terhadap pasar modal. Penelitian yang dilakukan oleh Dolley (1933) yang meneliti tentang pengaruh stock split terhadap harga saham mungkin merupakan event study yang pertama kali dilakukan, meskipun tidak menggunakan metodologi event study seperti yang dikenal sekarang.

Penelitian yang dilakukan oleh Myers \& Bakay (1948), Barker (1956,
1957, 1958) dan Ashley (1962) adalah beberapa contoh event study pada periode awal 1930-an hingga akhir 1960-an, periode dimana event study mengalami perkembangan luar biasa. Ball \& Brown (1968) serta Fama et al (1969) kemudian memperkenalkan metodologi event study seperti yang banyak digunakan saat ini.

Walaupun event study memiliki jangkauan yang luas, namun baru sekitar dua dekade terakhir ini banyak digunakan terhadap peristiwa-peristiwa di luar isu-isu ekonomi (Suryawijaya \& Setiawan, 1998). Beberapa isu diluar isu ekonomi yang telah diteliti di antaranya adalah isu lingkungan tentang kecelakaan reaktor nuklir Chernobyl oleh Kalra et al (1993), isu sosial tentang kecelakaan penerbangan pesawat DC-10 oleh Mansur et al (1989), atau isu politik tentang pengunduran diri Perdana Menteri Jepang oleh Asri (1996). Indikasi makin banyaknya penelitian yang berbasis pada event study yang mengambil kaitan antara perubahan harga saham dengan berbagai peristiwa atau informasi yang tidak terkait langsung dengan aktivitas ekonomi menunjukkan makin terintegrasinya peran pasar modal dalam kehidupan sosial masyarakat dunia (Suryawijaya \& Setiawan, 1998). Tabel di bawah ini menunjukkan beberapa penelitian lain yang mengkaji tentang anomali pasar modal. 
Tabel 1. Studi Terdahulu

\begin{tabular}{|c|c|c|c|}
\hline No & $\begin{array}{l}\text { Peneliti dan Tahun } \\
\text { Penelitian }\end{array}$ & Judul Penelitian & Metode dan Hasil Penelitian \\
\hline 1 & Deyshappriya (2014) & $\begin{array}{l}\text { An Empirical Investigation } \\
\text { on Stock Market } \\
\text { Anomalies; The Evidence } \\
\text { form Colombo Stock } \\
\text { Exchange in Sri Lanka }\end{array}$ & $\begin{array}{l}\text { Penelitian menggunakan metode } \\
\text { Ordinary Least Square dan GARCH. } \\
\text { Hasilnya adalah bahwa pada periode } \\
\text { perang Kolombo, negative Monday dan } \\
\text { positive January terjadi secara } \\
\text { signifikan. Sementara pasca perang, } \\
\text { tidak teridentifikasi terjadinya negative } \\
\text { December. }\end{array}$ \\
\hline 2 & Sharma et al (2014) & $\begin{array}{llr}\text { Month of } \quad \text { The } & \text { Year } \\
\text { Anomalies } \quad \text { in } & \text { Stock } \\
\text { Markets: Evidence } & \text { From } \\
\text { India } & & \\
\end{array}$ & $\begin{array}{l}\text { Dengan menggunakan model regresi } \\
\text { variabel dummy, penelitian menemukan } \\
\text { keberadaan month of the year anomalies } \\
\text { di India. }\end{array}$ \\
\hline 3 & Khan et al (2014) & $\begin{array}{l}\text { Calendar Anomalies, } \\
\text { Reality or an Illusion? } \\
\text { KSE-Pakistan }\end{array}$ & $\begin{array}{l}\text { Seperti kebanyakan penelitian lain, } \\
\text { penelitian ini menggunakan analisis } \\
\text { regresi. Hasil penelitian menunjukkan } \\
\text { bahwa tidak terjadi turn-off the month di } \\
\text { KSE Pakistan. }\end{array}$ \\
\hline 4 & Iqbal et al (2013) & $\begin{array}{l}\text { Conventional and Islamic } \\
\text { Anomalies in Karachi Stock } \\
\text { Exchange }\end{array}$ & $\begin{array}{l}\text { Dengan menggunakan Ordinary Least } \\
\text { Square, penelitian ini menyimpulkan } \\
\text { bahwa telah terjadi negative Monday, } \\
\text { positive Friday, half-month effect, turn- } \\
\text { off the month, month of the year, dan } \\
\text { anomali Ramadhan secara signifikan di } \\
\text { Pakistan }\end{array}$ \\
\hline 5 & Hepsen (2012) & $\begin{array}{l}\text { Calendar Anomalies and } \\
\text { Turkish Real Estate } \\
\text { Investment Trust (REITs) }\end{array}$ & $\begin{array}{l}\text { Metode penelitian ini adalah analisis } \\
\text { regresi berganda dengan menggunakan } \\
\text { variabel dummy. Hasilnya, pada saham } \\
\text { properti di Turki secara signifikan terjadi } \\
\text { negative Monday dan positive turn of the } \\
\text { month. }\end{array}$ \\
\hline 6 & Yat et al (2011) & $\begin{array}{lcc}\text { Sectoral } & \text { Analysis } & \text { of } \\
\text { Calendar } & \text { Effects } & \text { in } \\
\text { Malaysia: } & \text { Post Financial } \\
\text { Crisis (1998-2008) }\end{array}$ & $\begin{array}{l}\text { Dengan menggunakan uji akar unit, } \\
\text { analisis regresi dan GARCH, penelitian } \\
\text { menyimpulkan bahwa January effect dan } \\
\text { Monday effect terbukti ada di Malaysia } \\
\text { secara signifikan. }\end{array}$ \\
\hline 7 & Depenchuk et al (2010) & $\begin{array}{l}\text { Ukrainian } \quad \text { Financial } \\
\text { Markets: an Examination of } \\
\text { Calendar Anomalies }\end{array}$ & $\begin{array}{l}\text { Analisis regresi berganda yang } \\
\text { digunakan dalam penelitian ini tidak } \\
\text { berhasil membuktikan adanya January } \\
\text { effect dan weekend effect di pasar saham } \\
\text { Ukraina }\end{array}$ \\
\hline 8 & Chen et al (2010) & $\begin{array}{l}\text { Investigating Seasonal } \\
\text { Anomalies in Asian Stock } \\
\text { Market Prices:A Stochastic } \\
\text { Dominance Approach }\end{array}$ & $\begin{array}{l}\text { Berbeda dengan penelitian lain, } \\
\text { penelitian ini menggunakan Davidson } \\
\text { and Duclos Test. Hasilnya, pada } \\
\text { beberapa pasar saham di Asia (Taiwan, } \\
\text { Hongkong, dan Singapura), January } \\
\text { effect } \text { secara signifikan tidak terjadi. }\end{array}$ \\
\hline 9 & $\begin{array}{l}\text { Brounen dan Ben-Hamo } \\
\text { (2009) }\end{array}$ & $\begin{array}{l}\text { Calendar Anomalies: The } \\
\text { Case of International } \\
\text { Property Shares }\end{array}$ & $\begin{array}{l}\text { Dengan menggunakan analisis regresi, } \\
\text { penelitian ini menemukan bahwa pada } \\
\text { saham properti internasional, terbukti } \\
\text { adanya negative Monday, positive } \\
\text { Friday, dan positive January. }\end{array}$ \\
\hline
\end{tabular}




\begin{tabular}{|c|l|l|l|}
\hline 10 & Imandani (2008) & $\begin{array}{l}\text { Analisa Anomali Kalender } \\
\text { Terhadap Return di Bursa } \\
\text { Efek Indonesia }\end{array}$ & $\begin{array}{l}\text { Penelitian ini menggunakan analisis } \\
\text { regresi berganda. Hasilnya, holiday effect } \\
\text { terbukti ada secara signifikan di } \\
\text { Indonesia. }\end{array}$ \\
\hline 11 & $\begin{array}{l}\text { Greenstone dan Oyer } \\
(2000)\end{array}$ & $\begin{array}{l}\text { Are There Sectoral } \\
\text { Anomalies Too? The } \\
\text { Pitfalls of Unreported } \\
\text { Multiple Hypothesis Testing } \\
\text { anda Simple Solution }\end{array}$ & $\begin{array}{l}\text { Dengan menggunakan Bonferroni } \\
\text { Correction, penelitian ini gagal } \\
\text { membuktikan adanya dampak anomali } \\
\text { kalender di USA }\end{array}$ \\
\hline
\end{tabular}

\section{METODE PENELITIAN}

\section{Populasi dan Sampel Penelitian}

Populasi dan sampel yang digunakan dalam penelitian ini adalah saham-saham syariah yang terdaftar dalam JII (Jakarta Islamic Index). Indeks ini lebih dipilih karena menampilkan 30 saham syariah terbaik, sehingga akan memberikan hasil yang lebih baik untuk menggambarkan bagaimana saham syariah memberikan reaksi terhadap serangkain aksi bela Islam.

\section{Jenis dan Sumber Data}

Data yang akan digunakan penelitian ini merupakan data sekunder yang terdiri dari:

a. Daftar saham perusahaan yang termasuk dalam JII selama periode penelitian untuk masing-masing sampel peristiwa, diperoleh dari website

resmi Bursa Efek Indonesia (www.idx.co.id).

b. Data return dan volume perdagangan saham syariah 10 hari sebelum dan 10 hari sesudah aksi bela Islam 212 yang diambil dari website $\underline{w w w . s a h a m o k . c o m}$.

\section{Metode Analisis}

Metode analisis yang digunakan salam penelitian ini adalah uji beda dua rata-rata atau paired sample t-test. $\mathrm{Uji}$ beda dua rata-rata di dalam penelitian ini diuji menggunakan uji paired samplet-test dengan membandingkan antara return dan volume perdagangan saham syariah sebelum dan sesudah aksi bela Islam 212 yang berlangsung di Jakarta. Paired sample t-test atau uji-t sampel berpasangan merupakan uji parametrik yang digunakan untuk menguji apakah ada perbedaan ratarata dua sampel yang berhubungan (Ghozali, 2006). Teknik pengujian dilakukan dengan menggunakan paired sample t-test karena adanya data kemungkinan terdistribusi normal.

1. Jika probabilitas $>0,05$ maka Ho diterima dan Ha ditolak.

2. Jika probabilitas $\leq 0,05$ maka $\mathrm{Ho}$ ditolak Ha diterima.

\section{PEMBAHASAN}

\section{Objek Penelitian}

Penelitian ini mengambil sampel penelitian saham syariah yang masuk 
dalam Jakarta Islamic Index (JII). Indeks JII adalah salah satu indeks saham yang ada pada Bursa Efek Indonesia yang menghitung indeks rata-rata 30 saham yang memenuhi kriteria syariah, berkapitalisasi pasar terbesar, dan mempunyai tingkat likuiditas nilai perdagangan yang tinggi. Indeks ini diluncurkan pada bulan Juni 2000 dan dievaluasi setiap enam bulan sekali.

Daftar 30 saham yang masuk dalam periode penelitian ini didasarkan pada Pengumuman Bursa Efek Indonesia yang menetapkan saham syariah pada JII untuk periode Desember 2016 - Mei 2017. Adapun ke-30 saham yang dimaksud ditunjukkan oleh tabel 2.

Tabel 2. Daftar Saham Syariah Periode Desember 2016 - Mei 2017

\begin{tabular}{|l|l|l|}
\hline No & \multicolumn{1}{|c|}{ Kode } & \\
\hline 1 & AALI & Astra Argo Lestari Tbk \\
\hline 2 & ADHI & Adhi Karya (Persero) Tbk \\
\hline 3 & ADRO & Adaro Energy Tbk \\
\hline 4 & AKRA & AKR Corporindo Tbk \\
\hline 5 & ANTM & Aneka Tambang (Persero) Tbk \\
\hline 6 & ASII & Astra International Tbk \\
\hline 7 & BSDE & Bumi Serpong Damai Tbk \\
\hline 8 & ICBP & Indofood CBP Sukses Makmur Tbk \\
\hline 9 & INCO & Vale Indonesia Tbk \\
\hline 10 & INDF & Indofood Sukses Makmur Tbk \\
\hline 11 & INTP & Indocement Tunggal Prakasa Tbk \\
\hline 12 & KLBF & Kalbe Farma Tbk \\
\hline 13 & LPKR & Lippo Karawaci Tbk \\
\hline 14 & LPPF & Matahari Department Store Tbk \\
\hline 15 & LSIP & PP London Sumatra Indonesia Tbk \\
\hline 16 & MIKA & Mitra Keluarga Karyasehat Tbk \\
\hline 17 & MYRX & Hanson International Tbk \\
\hline 18 & PGAS & Perusahaan Gas Negara (Persero) Tbk \\
\hline 19 & PTBA & Tambang Batubara Bukit Asam Tbk \\
\hline 20 & PTPP & PP (Persero) Tbk \\
\hline 21 & PWON & Pakuwon Jati Tbk \\
\hline 22 & SILO & Siloam International Hospitals Tbk \\
\hline 23 & SMGR & Semen Indonesia (Persero) Tbk \\
\hline 24 & SMRA & Summarecon Agung Tbk \\
\hline 25 & SSMS & Sawit Sumbermas Sarana Tbk \\
\hline 26 & TLKM & Telekomunikasi Indonesia Tbk \\
\hline 27 & UNTR & United Tractors Tbk \\
\hline 28 & UNVR & Unilever Indonesia Tbk \\
\hline 29 & WIKA & Wijaya Karya (Persero) Tbk \\
\hline 30 & WSKT & Waskita Karya (Persero) Tbk \\
\hline
\end{tabular}

Dari daftar saham di atas, ada tiga saham yang baru masuk dalam periode ini, yaitu Adhi Karya (Persero) Tbk (ADHI), Aneka Tambang (Persero) Tbk (ANTM), dan Hanson International Tbk (MYRX), sedangkan tiga saham yang keluar dari periode ini adalah Alam Sutera Realty Tbk (ASRI), Jasa Marga (Persero) Tbk (JSMR), dan Surya Citra Media Tbk (SCMA).

\section{Hasil Penelitian}

Data return dan volume perdagangan saham syariah yang digunakan dalam penelitian ini adalah data 10 hari sebelum dan sesudah aksi bela Islam 212 tanggal 2 Desember 2016, sehingga total ada 20 hari aktif transaksi saham syariah yang diteliti. Gambaran umum data tersebut ditunjukkan pada tabel 3 .

Tabel 3. Statistik Deskriptif Data Penelitian

\begin{tabular}{|l|r|r|r|r|}
\hline Variable & Minimum & Maximum & \multicolumn{1}{|c|}{ Mean } & $\begin{array}{c}\text { Std. } \\
\text { Deviation }\end{array}$ \\
\hline Volume & $2 . \mathrm{E} 12$ & $5 . \mathrm{E} 12$ & $2.63 \mathrm{E} 12$ & $7.453 \mathrm{E} 11$ \\
\hline Return & .6640 & 15.5330 & $5.434238 \mathrm{E} 0$ & 3.6764583 \\
\hline
\end{tabular}

Dari tabel di atas, dapat dilihat beberapa gambaran umum mengenai fluktuasi volume dan return perdagangan saham syariah pada Jakarta Islamic Index. Nilai minimum volume transaksi saham syariah terjadi pada akhir periode penelitian, yakni tanggal 22 Desember 2016 dengan nilai sekitar Rp 2 triliun. 
Sementara itu, nilai maksimumnya terjadi dua hari sebelum aksi 212, yakni 30 November dengan nilai hampir mendekati Rp 5 triliun.

Berbeda dengan volume transaksi, return saham syariah memiliki nilai minimum sebesar Rp 0,664 serta nilai maksimum $\mathrm{Rp}$ 155.330. Nilai minimum tersebut terjadi pada tanggal 22 November 2016, sedangkan nilai maksimumnya terjadi pada 24 November. Hal ini menunjukkan bahwa nilai minimum dan maksimum return saham syariah terjadi sebelum aksi 212 dilakukan. Adapun rincian masing-masing nilai variabel ditunjukkan pada tabel berikut.

Tabel 4. Data Return dan Volume Saham JII Periode 18 November 2016 s/d 19 Desember 2016

\begin{tabular}{|c|c|c|}
\hline Tanggal & Volume & Return \\
\hline $18 / 11 / 2016$ & 2.106.622.337.605 & 52.420 \\
\hline $21 / 11 / 2016$ & 1.985 .707 .663 .063 & 43.090 \\
\hline $22 / 11 / 2016$ & 2.248.076.231.987 & 0,6640 \\
\hline $23 / 11 / 2016$ & 2.637 .712 .824 .038 & 57.860 \\
\hline $24 / 11 / 2016$ & 2.509.016.294.108 & 155.330 \\
\hline $25 / 11 / 2016$ & 1.955 .080 .613 .397 & 35.710 \\
\hline $28 / 11 / 2016$ & 2.175 .426 .218 .450 & 29.020 \\
\hline $29 / 11 / 2016$ & 2.485 .054 .470 .852 & 47.490 \\
\hline $30 / 11 / 2016$ & 4.819.294.099.632 & 29.120 \\
\hline $01 / 12 / 2016$ & 2.908.596.903.100 & 132.560 \\
\hline $02 / 12 / 2016$ & 2.423 .935 .190 .632 & 74.370 \\
\hline $05 / 12 / 2016$ & 2.277.540.319.932 & 50.120 \\
\hline $06 / 12 / 2016$ & 2.291 .368 .232 .773 & 27.240 \\
\hline $07 / 12 / 2016$ & 2.381 .481 .275 .600 & 49.550 \\
\hline $08 / 12 / 2016$ & 2.878 .828 .380 .679 & 56.950 \\
\hline $09 / 12 / 2016$ & 2.693 .362 .104 .090 & 11.710 \\
\hline $13 / 12 / 2016$ & 2.523 .446 .335 .570 & 19.150 \\
\hline $14 / 12 / 2016$ & 2.359.017.547.851 & 83.420 \\
\hline $15 / 12 / 2016$ & 2.821 .759 .005 .324 & 31.010 \\
\hline $16 / 12 / 2016$ & 4.595 .337 .881 .320 & 84.400 \\
\hline $19 / 12 / 2016$ & 2.070 .866 .666 .629 & 64.030 \\
\hline
\end{tabular}

Berdasarkan tabel di atas, dapat dilihat bahwa saham syariah juga mengalami anomali bulanan pada periode penelitian. Pada akhir bulan November, misalnya, transaksi saham syariah mengalami peningkatan signifikan hampir 100\%. Pada awal Desember, terjadi peningkatan return yang signifikan juga, hampir sebesar $400 \%$. Selain itu, anomali mingguan juga terjadi, seperti pada tanggal 16 Desember yang mengalami kenaikan volume transaksi dan return masingmasing hampir $60 \%$ dan $150 \%$.

Di sisi lain, dilihat melalui grafik, data volume perdagangan dan return saham syariah memiliki pola fluktuasi yang berbeda. Sebelum aksi bela Islam 212, volume perdagangan sempat naik signifikan pada H-2. Namun, beberapa hari pasca aksi, volume perdagangan menunjukkan pola stagnan sebelum kemudian kembali meningkat pada akhir periode penelitian.

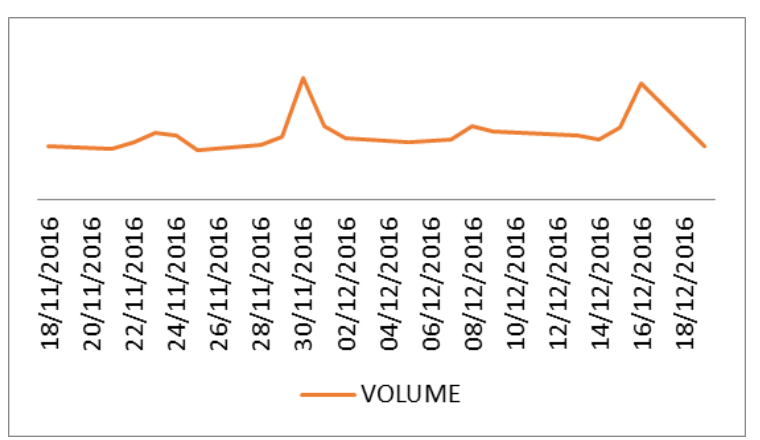

Gb. 1. Grafik Fluktuasi Volume Perdagangan Saham Syariah 
REAKSI PASAR MODAL SYARIAH TERHADAP

AKSI BELA ISLAM 212 DI JAKARTA

Return saham syariah menunjukkan pola pergerakan yang berbeda dengan volume transaksi. Variabel ini menunjukkan pola fluktuasi yang sama baik sebelum atau sesudah aksi bela Islam 212, meskipun fluktuasi sebelum aksi lebih tinggi daripada setelahnya. Grafik pergerakan return saham syariah ini dapat dilihat pada gambar di bawah ini.

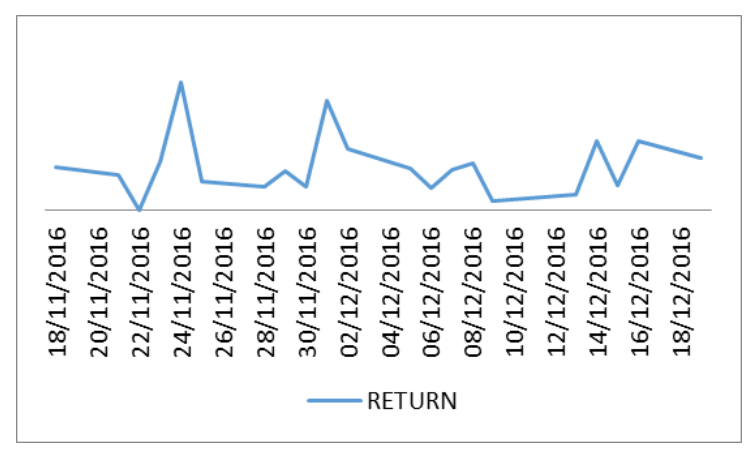

Gb. 2. Grafik Fluktuasi Return Saham Syariah

Grafik di atas menjelaskan bagaimana respon investor saham syariah dalam menanggapi aksi bela Islam 212 . Namun, untuk memastikan bagaimana respon investor, digunakan uji paired sample t-test terhadap volume dan return saham syariah. Dari uji ini, diperoleh hasil bahwa volume perdagangan saham syariah terbukti menunjukkan pergerakan yang berbeda antara sebelum dan sesudah aksi bela Islam (dengan signifikansi $<0,01$ ). Volume perdagangan setelah aksi bela Islam memiliki rata-rata yang lebih tinggi daripada sebelum aksi. Hasil ini ditunjukkan oleh tabel sebagai berikut.
Tabel 5. Hasil Uji Statistik terhadap Volume Perdagangan Saham Syariah

\begin{tabular}{|c|c|c|c|c|c|}
\hline Periode & Mean & $\mathbf{N}$ & $\begin{array}{c}\text { Std. } \\
\text { Deviation }\end{array}$ & $\begin{array}{c}\text { Std. Error } \\
\text { Mean }\end{array}$ & Sig. \\
\hline Sebelum & $2.5831 \mathrm{E} 12$ & 10 & $8.42045 \mathrm{E} 11$ & $2.66278 \mathrm{E} 11$ & \multirow{2}{*}{.001} \\
\hline Sesudah & $2.6893 \mathrm{E} 12$ & 10 & $7.17106 \mathrm{E} 11$ & $2.26769 \mathrm{E} 11$ & \\
\hline
\end{tabular}

Berdasarkan hasil uji statistik, return saham syariah sebelum dan sesudah aksi bela Islam 212 secara signifikan tidak terbukti memiliki perbedaan meskipun rata-rata return antara sebelum dan sesudah aksi memiliki margin yang menunjukkan bahwa rata-rata return sebelum aksi memiliki nilai yang lebih besar. Signifikansi paired sample t-test terhadap variabel ini menunjukkan nilai $0,387>$ 0,10 .

Tabel 4.5 Hasil Uji Statistik terhadap Return Saham Syariah

\begin{tabular}{|l|c|c|c|c|c|}
\hline Periode & Mean & N & $\begin{array}{c}\text { Std. } \\
\text { Deviation }\end{array}$ & $\begin{array}{c}\text { Std. Error } \\
\text { Mean }\end{array}$ & Sig. \\
\hline Sebelum & $5.83 \mathrm{E} 4$ & 10 & 48224.282 & 15249.857 & \multirow{2}{*}{387} \\
\cline { 1 - 5 } Sesudah & $4.78 \mathrm{E} 4$ & 10 & 25368.036 & 8022.077 & \\
\hline
\end{tabular}

\section{Pembahasan}

Hasil penelitian menunjukkan bahwa variabel volume perdagangan saham syariah menunjukkan perbedaan antara sebelum dan sesudah aksi bela Islam 212, sedangkan variabel return tidak terbukti mengalami perbedaan. Hasil ini menggambarkan bagaimana respon investor saham syariah terhadap aksi bela Islam 212 di Jakarta. 
Investor saham syariah tidak banyak melakukan transaksi sebelum aksi ini dilakukan oleh massa. Ini ditunjukkan dengan volume transaksi yang berbeda sebelum dan sesudah aksi. Transaksi perdagangan sesudah aksi bela Islam 212 memiliki nominal yang lebih besar, meskipun kenaikan nominal ini, berdasarkan gambar 4.1, baru terjadi pada tanggal 18 Desember 2017 atau hampir sekitar dua minggu pasca aksi. Jangka waktu yang cukup lama ini digunakan investor untuk memastikan stabilitas saham syariah pasca aksi bela Islam 212 .

Return saham syariah tidak terbukti mengalami perbedaan, sehingga dapat disimpulkan bahwa meskipun investor menurunkan aktifitas transaksinya sebelum aksi bela Islam 212, mereka tetap bersikap rasional dengan tidak menjual saham yang mereka miliki dengan harga yang rendah atau tanpa mendapat laba.

Perubahan nominal volume transaksi yang tidak disertai dengan perubahan return menunjukkan bahwa ada dua sikap yang diambil investor saham syariah dalam menanggapi aksi bela Islam 212, yaitu:

1. Investor protektif, yang lebih suka memegang saham yang dimilikinya sebelum memastikan bahwa aksi bela Islam 212 tidak memberikan gejolak terhadap bursa efek syariah.
2. Investor agresif rasional, yang tetap melakukan transaksi baik sebelum dan sesudah aksi, tetapi tetap menggunakan rasionalitas sehingga mereka menjual saham ketika memberikan laba.

\section{PENUTUP}

\section{Kesimpulan}

Hasil penelitian ini memberikan beberapa temuan yang menjawab beberapa pertanyaan yang diajukan dalam penelitian, yaitu:

1. Volume perdagangan saham syariah terbukti mengalami perbedaan sebelum dan sesudah aksi bela Islam 212 (dengan nominal volume transakis setelah aksi lebih besar). Hal ini menunjukkan bahwa sebelum aksi, sebagian investor lebih suka memegang saham yang mereka miliki daripada menjualnya.

2. Return saham syariah tidak terbukti mengalami perbedaan sebelum dan sesudah aksi. Temuan ini menunjukkan bahwa investor yang menjual saham sebelum aksi tetap bersikap rasional dengan tetap mempertimbangkan laba ketika melakukan transaksi. 


\section{Rekomendasi}

Berdasarkan hasil yang telah diperoleh, maka ada beberapa rekomendasi yang diberikan oleh penelitian ini, yaitu:

1. Bagi investor saham syariah, untuk tetap bersikap optimis dan tidak paranoid dalam menanggapi aksi-aksi yang serupa dengan aksi bela Islam 212 yang terjadi di Jakarta. Aksi-aksi seperti itu tidak memberikan dampak signifikan pada return saham syariah.

2. Bagi organisasi kemasyarakatan, agar mempertimbangkan dampak aksi massa terhadap perekonomian, baik dalam skala makro ataupun mikro.

3. Bagi penelitian selanjutnya, agar meneliti anomali bulanan dan mingguan yang terjadi pada saham syariah, karena penelitian ini menemukan adanya anomali tersebut pada periode yang diteliti.

\section{REFERENSI}

Al-Rabadi, D.W.H. dan Al-Qudah, K.A. 2012. Calendar Anomalies: The Case of Amman Stock Exchange. International Journal of Business and Management. Vol.7. No. 24: 120-127.

Ang, Robbert, 1997, Pasar Modal Indonesia (The Intelligent Guide to Indonesian Capital Market), Mediasoft Indonesia, Jakarta.

Brounen, D. dan Ben-Hamo, Y. 2009. Calendar Anomalies: The Case of International Property Shares. Journal of Real Estate, Financial and Economic. Vol. 38: 115-136.
Burhanuddin Susanto, Aspek Hukum Lembaga Keuangan Syariah, (Yogyakarta:

Graha Ilmu, 2010), 131.

Depenchuk, Iryna O. et al. 2010. Ukrainian Financial Markets: an Examination of Calendar Anomalies. Journal of Managerial Finance. Vol. 36 No. 6: 502-510.

Deyshappriya. 2014. An Empirical Investigation on Stock Market Anomalies; The Evidence form Colombo Stock Exchange in Sri Lanka. International Journal of Economics and Finance. Vol. 6 No. 3: 177-187.

Evianti, Weny. 2007. Analisa Dampak Tahun Baru China (Imlek) dan Uji Rogalski Effect Terhadap Return Saham. Skripsi. UIN Syarif Hidayatullah: Jakarta.

Fama, E.F. 1970. Efficient Capital Markets: a Review of Theory and Empirical Work. Journal of Finance. Vol. 25: 383-417.

Fatwa DSN-MUI No: 32/DSNMUI/IX/2002 tentang Obligasi Syariah

Fazal, J.S. et al. 2005. Seasonality in Stock Return and Volatility: The Ramadan Effect.

Greenstone, M. dan Oyer, P. 2000. Are There Sectoral Anomalies Too? The Pitfalls of Unreported Multiple Hypothesis Testing and a Simple Solution. Review of Quantitative Finance and Accounting. Vol. 15: 37-55.

Gumanti, T.A. dan Elok Sri Utami. 2002. Bentuk Pasar Efisien dan Pengujiannya. Jurnal Akuntansi \& Keuangan. Vol.4. No.1 (Mei). h.54-68.

Hepsen, Ali. 2012. Calendar Anomalies and Turkish Real Estate Investment Trust (REITs). International Journal of Economic and Finance. Vol. 4: 230-236. 
Imandani, Rama. 2008. Analisa Anomali Kalender Terhadap Return di Bursa Efek Indonesia. Skripsi. UIN Syarif Hidayatullah: Jakarta.

Iqbal, M.S. et al. 2013. Conventional and Islamic Anomalies in Karachi Stock Exchange. International Science. Vol. 25: 999-1007.

Jogiyanto. 2008. Teori Portofolio dan Analisis Investasi. Edisi Kelima. BPFE. Yogyakarta.

Jogiyanto. H.M. 2003. Teori Portofolio dan Analisis Investasi. Edisi 3. BPFE.

Yogyakarta.

Jones, C.P. 1996. Investment Analysis and Management. New York: John Wiley and Sons.

Khan, M.I. et al. 2014. Calendar Anomalies, Reality or an Illusion? KSE-Pakistan. Journal of Economics and International Finance. Vol. 6 No. 4: 80-84.

Kritzman, M. P. 1994. What Practitioners Need To Know About Event Studies. Financial Analyst Journal. November-December. h.17-20.

Lamasigi, Treisye Ariance, 2002, "Reaksi Pasar Modal Terhadap Peristiwa Pergantian Presiden Republik Indonesia 23 Juli 2001 : Kajian Terhadap Return Saham LQ-45 di PT Bursa Efek Jakarta”, Proceeding Simposium Nasional Akuntansi V, h.273-285.

M. Nasarudin Irsan dan Indra Surya, Aspek Hukum Pasar Modal Indonesia, (Jakarta: Kencana, 2007), 10.

M. Nasarudin Irsan dan Indra Surya, Aspek Hukum Pasar Modal Indonesia, 209.

MacKinlay, A. Craig, 1997, "Event Studies in Economics and Finance", Journal of Economic Literature, Vol.XXXV (March), h.13-39.

Munir Fuady, Pasar Modal Modern; Tinjauan Hukum Islam, (Bandung: PT. Citra
Raj, M. dan Kumari, D. 2006. Day of The Week and Other Market Anomaliesn in The Indian Stock Market. International Journal of Emerging Markets. Vol. 1: 235-246.

Sharma, et al. 2014. Month of The Year Anomalies in Stock Markets: Evidence from India. The International Journal of Applied Economics and Finance. Vol. 8 No.3: 82-97.

Sumantoro, dalam Khaerul Umam, Pasar Modal Syariah dan Praktik Pasar Modal Syariah, (Bandung: Pustaka Setia, 2013), 34.

Suryawijaya, M.A. dan F.A. Setiawan. 1998, Reaksi Pasar Modal Indonesia Terhadap Peristiwa Politik Dalam Negeri (Event Study pada

Peristiwa 27 Juli 1996). KELOLA. Vol.VII. No.18. h.137-153.

Susilo, dkk., Bank dan Lembaga Keuangan Lain, (Jakarta: Salemba, 2000), 189.

Tjiptono Darmadji dan Hendy $M$. Fakhruddin, Pasar Modal di Indonesia;

Pendekatan Tanya Jawab, (Jakarta: Salemba Empat, 2008), 1.

Yadi Nurhayadi, "Pasar Modal Syariah: Landasan Hukum dan Kritik atas Kinerjanya," dalam http://yadinurhayadi.files.wordpress. com, (03 April 2013).

Yat, et al. 2011. Sectoral Analysis of Calendar Effects in Malaysia: Post Financial Crisis (1998-2008). African Journal of Business Management. Vol. 5 No. 14: 56005611.

Yulfasni, Hukum Pasar Modal, (Jakarta: Badan Penerbit IBLAM, 2005), 1.

Aditya Bhakti, 2001), 10. 


\section{Artikel Internet}

BBC Indonesia. "Hadiri dzikir di Masjid Istiqlal, massa bawa spanduk 'wajib pilih pemimpin Muslim'". Diakses tanggal 25 April 2017.

BBC Indonesia. "Pidato di Kepulauan Seribu dan hari-hari hingga Ahok menjadi tersangka". Diakses tanggal 25 April 2017.

CNN Indonesia. "Selain Jakarta, Sejumlah Daerah Juga Gelar Aksi Tolak Ahok". Diakses tanggal 25 April 2017.

Detiknews.com. "Wapres JK Bertemu Perwakilan Massa Demo 4 November". Diakses tanggal 25 April 2017.

Detiknews.com."Koordinator Aksi 4 November Minta Massa Bawa Kantong untuk Tampung Sampah". Diakses tanggal 25 April 2017.

Kompas.com. Ini Keputusan Komisi III Setelah Temui Massa Aksi 212, diakses 25 April 2017.

news.okezone.com. "Teriakan Takbir Sambut Presiden Jokowi di Monas". Diakses tanggal 25 April 2017.

Newsliputan6.com. Aksi 31 Maret Digelar di Istana Merdeka Jakarta Hari Ini, diakses 25 April 2017.

Republika Online. "Habib Rizieq Jamin Aksi Bela Islam III Berjalan Super Damai". Diakses tanggal 25 April 2017.

Republika Online. "Ketua DPR Enggan Tanggapi Rencana Aksi Bela Islam Jilid III". Diakses tanggal 25 April 2017.

Sindonews.com. "Demo 4 November, Jokowi Pilih Tinjau Proyek Kereta Bandara". Diakses tanggal 25 April 2017.

Sindonews.com. "Demo 4 November, Massa dari Luar Kota Mulai Berdatangan ke Jakarta". Diakses tanggal 25 April 2017.
Tempo.com. "Begini Kondisi Massa Aksi 112 di Tengah Guyuran Hujan". Diakses tanggal 25 April 2017.

VIVA.co.id. "Kata Kapolri Soal Aksi Bela Islam III". Diakses tanggal 25 April 2017.

Pengumuman Bursa Efek Indonesia Nomor Peng-00917/BEI.OPP/11-2016 tanggal 29 November 2016. 